\title{
Determination of Total Phenolic and Total Flavonoid Contents and Assessment of Antioxidant Properties of Cameroon Propolis: Case of Boyo (North-West Cameroon)
}

\author{
Madjitoloum Betoloum Salomon ${ }^{1 *}$, Laokein Basile ${ }^{2}$, Allaramadji Ngarmadji Constant ${ }^{3}$ \\ ${ }^{1}$ Department of Chemistry-Faculty of Science and Technology-University Adam Barka of Abéché. Chad \\ ${ }^{2}$ Department of Physics and Chemistry. Higher teacher's training college of N'Djamena, Chad \\ ${ }^{3}$ Department of Chemistry. Faculty of Exact and Applied Sciences. University of N'Djamena, Chad
}

*Corresponding Author

Madjitoloum Betoloum Salomon

\author{
Article History \\ Received: 11.03 .2021 \\ Accepted: 18.04 .2021 \\ Published: 30.04 .2021
}

\begin{abstract}
The present work deals with the qualitative and quantitative analyses and the assessment of the antioxidant properties of the extracts of the propolis of Boyo. It appears from this study that the polarity of the solvent used and the yield obtained are inversely proportional. We see here that hexane, apolar solvent presents an extraction yield of $52.08 \%$ while methanol, the most polar solvent presents only a yield of $5.21 \%$. The qualitative analysis shows that these extracts contain enough compounds of natural substances and rich in polyphenols in particular flavonoids. The quantification of polyphenols is $0.68 \pm 0.09 \mathrm{~g}$ EAG/100 $\mathrm{g} \mathrm{MB}$ for the hexane extract, $2.64 \pm 0.43 \mathrm{~g}$ EAG/100 $\mathrm{g}$ MB for the ethyl acetate extract and $12.64 \pm 0.23 \mathrm{~g} \mathrm{EAG} / 100 \mathrm{~g} \mathrm{MB}$ for the methanol extract, then that of flavonoids is $0.21 \pm 0.05 \mathrm{~g} \mathrm{QE} / 100 \mathrm{~g}$ $\mathrm{MB}$ for the hexane extract, $0.92 \pm 0.03 \mathrm{~g} \mathrm{QE} / 100 \mathrm{~g} \mathrm{MB}$ for the ethyl acetate extract and $2.02 \pm 0.02 \mathrm{~g} \mathrm{QE} / 100 \mathrm{~g} \mathrm{MB}$ for the methanol extract. The study of antioxidant activities and the quantification of phenolic compounds of these same extracts showed interesting properties that propolis extracts possess.
\end{abstract}

Keywords: Phytochemistry, antioxidant properties, Propolis and Boyo in Cameroon.

\section{INTRODUCTION}

The bee is a social insect of the order Hymenoptera, born in the Cretaceous period more than one hundred million years ago. Associated with the image of honey, it has always fascinated men who have gradually learned to raise, maintain and care for it. Apis mellifera is the most interesting species in beekeeping. Originally from Asia, it has been disseminated by man throughout the world [1].

Thus, the products resulting from the work of this small insect have been used for thousands of years and their uses are found in many civilizations and other beliefs. Formidably well organized in society, bees represent an interesting subject of study while bringing pleasure, health, happiness and income to a whole world [2]. In fact, taking advantage of the growing popularity of natural or so-called alternative medicines, bee products are part of this trend, most often as a complement to conventional treatments. Honey, royal jelly, propolis, pollen or even beeswax and venom are used in a wide variety of therapeutic fields to satisfy the demands of a public eager to find simple, natural and healthy ways to treat themselves.

More and more practiced in the world, apitherapy or the medical use of these products of the hive is the subject of several scientific studies, but which remain however too few or incomplete. Also, it is a form of medicine that evolves from one year to the next according to the plants foraged and the bee itself, contrary to certain synthetic molecules such as antibiotics for example, which are subject to resistance phenomena observed in certain pathogenic germs [2]. Among these products from the hive, only one is the subject of this study: propolis. Considered as one of the oldest remedies of humanity, known and used since the highest antiquity, propolis has its beneficial effects on the defense system of the

Copyright (C) 2021 The Author(s): This is an open-access article distributed under the terms of the Creative Commons Attribution 4.0 International License (CC BY-NC 4.0) which permits unrestricted use, distribution, and reproduction in any medium for non-commercial use provided the original author and source are credited. 
body are now known and its regular consumption in addition to a good food hygiene makes it an essential element of daily health. Unfortunately, it was neglected for economic reasons by the pharmaceutical industry before being totally forgotten at the beginning of the 20th century [1]. This product of the hive is very valuable because of its antioxidant [3, 4 and 5], antibacterial [6, 3, 4, 7], antiviral [6, 3], anticancer [3] and therapeutic properties related to its composition in polyphenols and flavonoids. To this end, propolis is extensively used in the food industry, medicine, cosmetology and veterinary medicine. As far as we know, in Cameroon, apart from the antibacterial activities performed by Mbawala et al., [8-10]; antiradical activities performed by Njingtang et al., [11] and analgesic activity performed by Talla et al., [12], some therapeutic virtues of this product have not yet been explored. It is time to discover the virtues of Cameroonian propolis.

For the sake of scientific investigation and the desire to integrate traditional medicine into the vast field of therapy for the well-being of mankind, we have directed one of its research axes to natural substances. Our contribution to the realization of this vast program has focused on the phytochemical and pharmacological study of a product of the hive, Propolis. The use of this one in many civilizations shows that it has very varied medicinal virtues. It is thus for a detailed chemical investigation of these active principles that we undertook its study.

\section{Material ANd Methods \\ Raw Material}

The raw material of our study is a propolis harvested in April 2020. It was purchased with the beekeepers in a site of sale of the apiarian products of the locality of Boyo, Region of the North-West of Cameroon. A powder of this material was obtained after trituration of the raw propolis. This powder is then used for the extractions.

\section{Extraction Procedure}

$1.2 \mathrm{~kg}$ of propolis powder was introduced in a container with a volume of 6 liters of distilled hexane, the whole is closed and left to rest, after 72 hours, the mixture was filtered and the filtrate was then concentrated with rotavapor. The residue was subjected to the same treatment with ethyl acetate, and finally the residue of the ethyl acetate extract was subjected to the same treatment with methanol. We note that for the same solvent this operation is repeated three times. The yield of the extraction thus obtained expressed in percentage compared to the mass of the starting propolis powder and is calculated by the formula below:

$$
\text { Yield }=\frac{\text { Mass of the extract }}{\text { Mass of the propolis powder }} \times 100
$$

\section{Qualitative analysis of chemical compounds}

A phitochemical screening was done on the families of compounds such as alkaloids, polyphenols (flavonoids, anthocyanins, tannins), saponosides, steroids, coumarins, sterols, terpenes, cardiotonic heterosides, essential oils, reducing sugars according to the protocol of Betoloum et al., [13]. Previous work on propolis extracts shows that they contain enough families of these compounds [14].

\section{Quantitative analysis of chemical compounds Determination of total phenolic content (TPC)}

Phenolic compounds, form a large heterogeneous group of secondary plant metabolites. They are widespread in the plant kingdom, synthesized by several voices, to the point that they form a very large group of substances that is difficult to define simply. They participate in the defense of plants against environmental aggressions. We determined total polyphenols using the Folin-Ciocalteu reagent, a method described as early as 1965 by Singleton and Rossi [15], modified by Madjitoloum et al., The reagent is a mixture of phosphotungstic acid $\left(\mathrm{H}_{3} \mathrm{PW}_{12} \mathrm{O}_{40}\right)$ and phosphomolybdic acid $\left(\mathrm{H}_{3} \mathrm{PMo}_{12} \mathrm{O}_{40}\right)$. It is reduced, during the oxidation of phenols, to a mixture of blue oxides of tungsten and molybdenum. The coloration produced, whose maximum absorption is between 725 and $750 \mathrm{~nm}$, is proportional to the quantity of polyphenols present in the plant extracts [16]. Total phenolic contents of the samples determined from the calibration curve equation $\left(y=0.1236 x \mathrm{R}^{2}=0.9831\right)$ were expressed in mg Gallic Acid Equivalents $(\mathrm{GAE}) / 100 \mathrm{~g}$ of Brut Material. All measurements were performed in three replications.

\section{Determination of total flavonoid content (TFC)}

The estimation of total flavonoid content in propolis extracts is performed by the method described by Hariri et al., [17], modified by Betoloum et al., [13].

Total flavonoid content of the extracts were evaluated using UV spectroscopic method. A volume of methanolic solution of aluminum chloride $(0.5 \mathrm{~mL}, 2 \% \mathrm{w} / \mathrm{v})$ was mixed with the methanolic solution of the extract $(0.5 \mathrm{~mL}, 0.1$ $\mathrm{mg} / \mathrm{mL}$ ). After $10 \mathrm{~min}$., absorbances were measured at $415 \mathrm{~nm}$. Results, determined from de the calibration curve equation $\left(y=0,009 x, R^{2}=0,9963\right)$ were calculated as follows and expressed in $\mathrm{mg}$ of Quercetin Equivalents $(\mathrm{QE}) / 100 \mathrm{~g}$ brut material $(\mathrm{BM})$ : 
$\mathrm{TFC}=\frac{0.05 \times \mathrm{A}_{\mathrm{ext}} \times 100}{\mathrm{~A}_{\mathrm{q}} \times \mathrm{C}_{\mathrm{ext}}}$, where TFC: total flavonoids content (mg QE/100g BM); Aext.: absorbance of the extract; Aq.: absorbance of quercetin; Cext.: concentration of plant extract $(10 \mathrm{mg} / \mathrm{mL})$.

All measurements were performed in three replications.

\section{Assessment of antioxidant activities}

The antioxidant activities of bee propolis extracts are evaluated by two different methods: the iron reducing power and the anti-free radical activity with DPPH.

\section{Anti-free radical activity with DPPH}

The antioxidant activity of propolis extracts is determined by the DPPH test, using the method described by Laskar et al., [18]. The 1,1-diphenyl-2-picryl-hydrazyl (DPPH) is defined as a stable free radical by virtue of the delocalization of the available electron that causes the deep purple color, characterized by absorption. It reacts with amine groups, phenols, acids, hydro-aromatic compounds, etc. This property is widely recommended and used in analytical practice. When the solution of DPPH is mixed with that of a substance that can donate a hydrogen atom or an electron, then this causes the reduced form (1,1-diphenyl-2-(2,4,6-trinitrophenyl) -hydrazine (DPPH)) with the loss of the purple color and appearance of a pale yellow residual color due to the presence of picryl group. The percentage of inhibition of the DPPH radical is calculated by the formula:

$$
\% \text { inhibition }=\frac{A_{c}(0)-A_{s}(t)}{A_{c}(0)} \times 100
$$

With $\operatorname{Ac}(0)$ : Absorbance of the control and $\operatorname{As}(\mathrm{t})=$ Absorbance of the sample

\section{Reducing power of iron}

The chelating power of iron ions was measured according to the method of Suter and Richter 2000 with slight modifications from Betoloum et al., [13]. The reagent solution contained $100 \mu \mathrm{L}(2 \mathrm{mM})$ of ferric chloride $\left(\mathrm{FeCl}_{3}\right), 400 \mu \mathrm{L}$ $(5 \mathrm{mM})$ potassium hexacyanoferrate $\left(\mathrm{K}_{3}\left[\mathrm{Fe}(\mathrm{CN})_{6}\right]\right)$, and $200 \mu \mathrm{L}$ of sample at different concentrations $(50 \mathrm{Ho} 200 \mathrm{mg} / \mathrm{mL})$. Distilled water was added to have a total volume of $1 \mathrm{~mL}$. The reaction mixture was incubated at $20^{\circ} \mathrm{C}$ for $10 \mathrm{~min}$.

The formation of potassium hexacyanoferrate complex was measured at 700nm using a spectrometer (Raleigh). The experiment was performed at $20^{\circ} \mathrm{C}$ to prevent oxidation of $\mathrm{Fe}^{2+}$. The lower absorbances indicated a high iron chelating capacity. EDTA was used for comparison. The percentage of iron ion chelating capacity (PCIF) was determined according to the formula :

$$
\% \text { IICP }=\frac{\mathrm{OD}_{\text {control }}-\mathrm{OD}_{\text {extract }}}{O \mathrm{D}_{\text {control }}}
$$

Where, IICP: Iron Ion Chelating Power and OD: Optical Density.

\section{RESULTS AND DisCUSSIONS \\ RESULTS \\ Yield of extraction}

The yield extractions of propolis according to the different organic solvents used, are schown in Table- 1 .

Table-1: Extraction yield

\begin{tabular}{|l|l|l|l|}
\hline Extracts & Mass of the propolis powder $(\mathbf{g})$ & Mass of the extracts $(\mathrm{g})$ & Extraction yield (\%) \\
\hline Hexane & 1200 & 625 & 52.08 \\
\hline ethyl acetate & 1200 & 287.5 & 23.96 \\
\hline Methanol & 1200 & 62.5 & 5.21 \\
\hline
\end{tabular}

It appears from this table that the polarity of the solvent used and the yield obtained are inversely proportional. We see here that hexane, apolar solvent presents an extraction yield of 52.08\% whereas methanol, the most polar solvent presents only a yield of $5.21 \%$.

\section{Exploratory qualitative analysis of the extracts}

The method of analysis used allowed us to know the chemical composition of various extracts of propolis from the locality of Boyo (North-West of Cameroon). The results of this analysis are designed in Table- 2 below. 
Table-2: Phytochemical screening of the extract with hexane, ethyl acetate and methanol

\begin{tabular}{|l|r|r|r|}
\hline \multirow{2}{*}{ Family of compounds } & \multicolumn{3}{|c|}{ Results } \\
\cline { 2 - 4 } & Hexane extract & Ethyl acetate extract & Methanol extract \\
\hline Alkaloids & - & + & + \\
\hline Triterpenes & + & + & + \\
\hline Sterols & - & - & + \\
\hline Flavonoids & - & - & + \\
\hline Polyphenols & + & + & + \\
\hline Tannins & + & + & - \\
\hline Coumarins & - & - & - \\
\hline Free Anthracenes & - & - & + \\
\hline Saponins & - & - & + \\
\hline Combined Anthracenes : & & + & + \\
O-Heterosides & - & + & \\
C-Heterosides & - & + & \\
\hline
\end{tabular}

$+:$ presence of the compound family; - : absence of the compound family

\section{Quantitative Analysis}

The results of the quantitative analyses by spectrophotometer visible UV of the different extracts are shown in Table-3. The method used is the one of Betoloum et al., [13]. In the survey, the absorbance of a set of concentrations of gallic acid and quercetin led to the curves of standardization with the equations and coefficients of correlation, respectively: $y=0.1236 x, R^{2}=0.9831$ for gallic acid and $y=0,009 x, R^{2}=0,9963$ for quercetin.

These results reflect the rich content of the plant in phenolic compounds as flavonoids and phenols. Table-3 and Figure-1 shows the total phenol content and total flavonoid content.

Table-3: Total polyphenols and totals flavonoids contents

\begin{tabular}{|l|l|l|}
\hline Extraits & Total polyphenols contents (gEGA/100g BM) & Total flavonoids contents (gEQ/100g BM) \\
\hline EH & $0.68 \pm 0.09$ & $0.21 \pm 0.05$ \\
\hline EAcOEt & $2.64 \pm 0.43$ & $0.92 \pm 0.03$ \\
\hline EMeOH & $12.64 \pm 0.23$ & $2.02 \pm 0.02$ \\
\hline
\end{tabular}

HE: hexane extract; AcOEtE: ethyl acetate extract et MeOHE: methanol extract

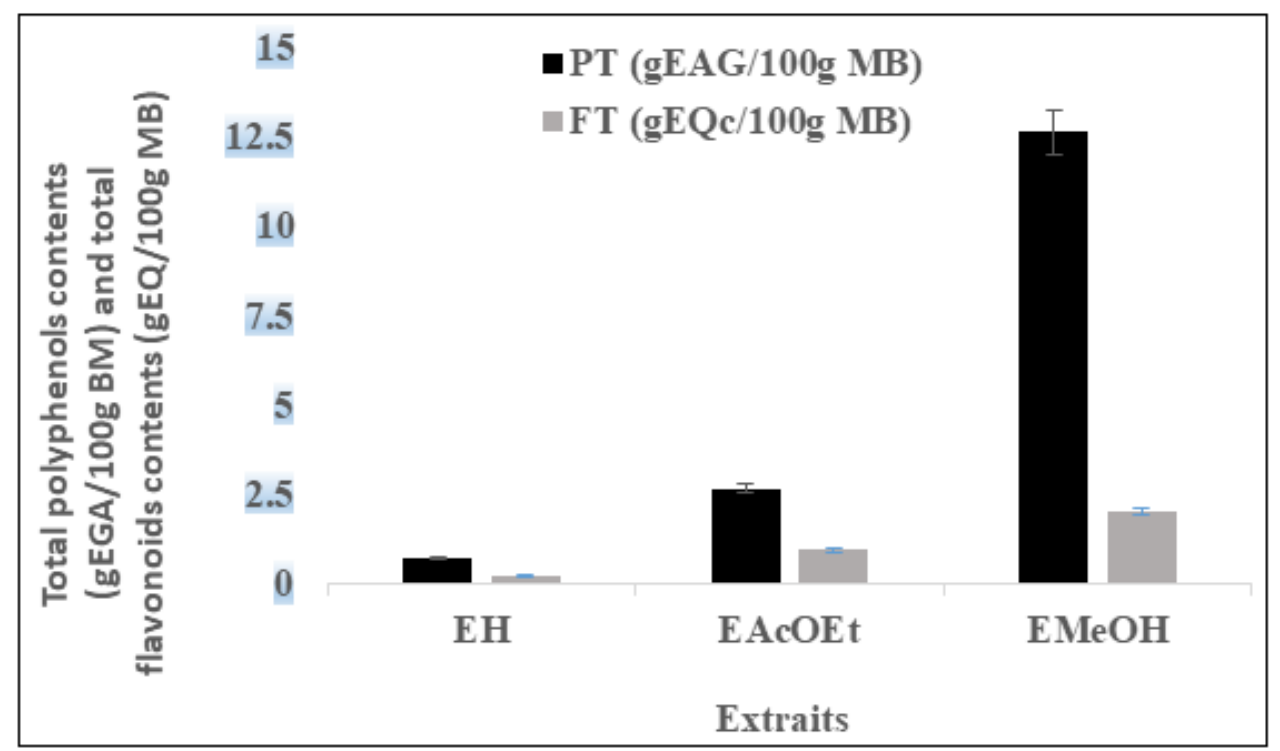

Fig-1: Total polyphenols and total flavonoids contents (g/100g MB)

EH: hexane extract; EAcOEt: ethyl acetate extract and EMeOH: methanol extract

\section{Anti-oxidant activity of the extracts}

The antioxidant activity of a compound corresponds to its capacity to resist oxidation. The best known antioxidants are $\beta$-carotene (provitamin A), ascorbic acid (vitamin $\mathrm{C}$ ), tocopherol (vitamin E) and phenolic compounds. Indeed, most of the synthetic or naturally occurring antioxidants have hydroxyphenolic groups in their structures and the 
antioxidant properties are attributed in part, to the ability of these natural compounds to scavenge free radicals such as hydroxyl $\left(\mathrm{OH}^{-}\right)$and superoxide $\left(\mathrm{O}^{2-}\right)$ radicals [19].

Several methods are used to evaluate, in vitro and in vivo, the antioxidant activity by scavenging different radicals, such as $\mathrm{ROO}^{-}$peroxides by the ORAC (Oxygen Radical Absorbance Capacity) and TRAP (Total RadicalTrapping Antioxidant Parameter) methods [20] ; ferric ions by the FRAP (Ferric ion Reducing Antioxidant Parameter) method [21]; or ABTS- radicals (ammonium salt of 2,2'-azinobis-3-ethylbenzothiazoline-6-sulfonic acid), as well as the method using the free radical DPPH- (diphenyl-picrylhydrazyl) [22].

Given the complexity of oxidation processes and the diverse nature of antioxidants, with both hydrophilic and hydrophobic components, there is no universal method by which antioxidant activity can be quantitatively measured in a precise manner. Most often, it is necessary to combine the responses of different and complementary tests to get an indication of the antioxidant capacity of the test sample [23].

For this reason, we have used a method based on the iron reducing potential and another based on the DPPH free radical scavenging activity.

\section{Reducing power of iron}

This antioxidant activity is based on the reduction of Iron (III) present in the $\mathrm{K}_{3} \mathrm{Fe}(\mathrm{CN})_{6}$ complex to Iron (II) [24]. The results of iron reducing power of hexane, ethyl acetate and methanol extracts of the studied propolis are represented in Table-4 and Figure-2.

Table-4: Iron reducing power of propolis extracts.

\begin{tabular}{|l|l|l|l|l|l|l|l|}
\hline EDTA & \multicolumn{2}{l}{ HE } & AcOEtE & MeOH E \\
\hline C $(\mathbf{m g} / \mathbf{m L})$ & IRP $(\boldsymbol{\%})$ & $\mathbf{C}(\mathbf{m g} / \mathbf{m L})$ & IRP $(\boldsymbol{\%})$ & $\mathbf{C}(\mathbf{m g} / \mathbf{m L})$ & IRP $(\boldsymbol{\%})$ & $\mathbf{C}(\mathbf{m g} / \mathbf{m L})$ & IRP $(\boldsymbol{\%})$ \\
\hline 0 & 0 & 0 & 0 & 0 & 0 & 0 & 0 \\
\hline 50 & 38.24 & 50 & 22.58 & 50 & 30.28 & 50 & 35.18 \\
\hline 100 & 50.13 & 100 & 27.89 & 100 & 33.28 & 100 & 47.33 \\
\hline 150 & 60.62 & 150 & 29.68 & 150 & 38.15 & 150 & 54.78 \\
\hline 200 & 69.03 & 200 & 32.59 & 200 & 46.11 & 200 & 62.94 \\
\hline
\end{tabular}

EDTA: Ethylene Diamine Tetraacetic Acid, HE: hexane extract; AcOEtE: ethyl acetate extract and MeOHE: methanol extract.

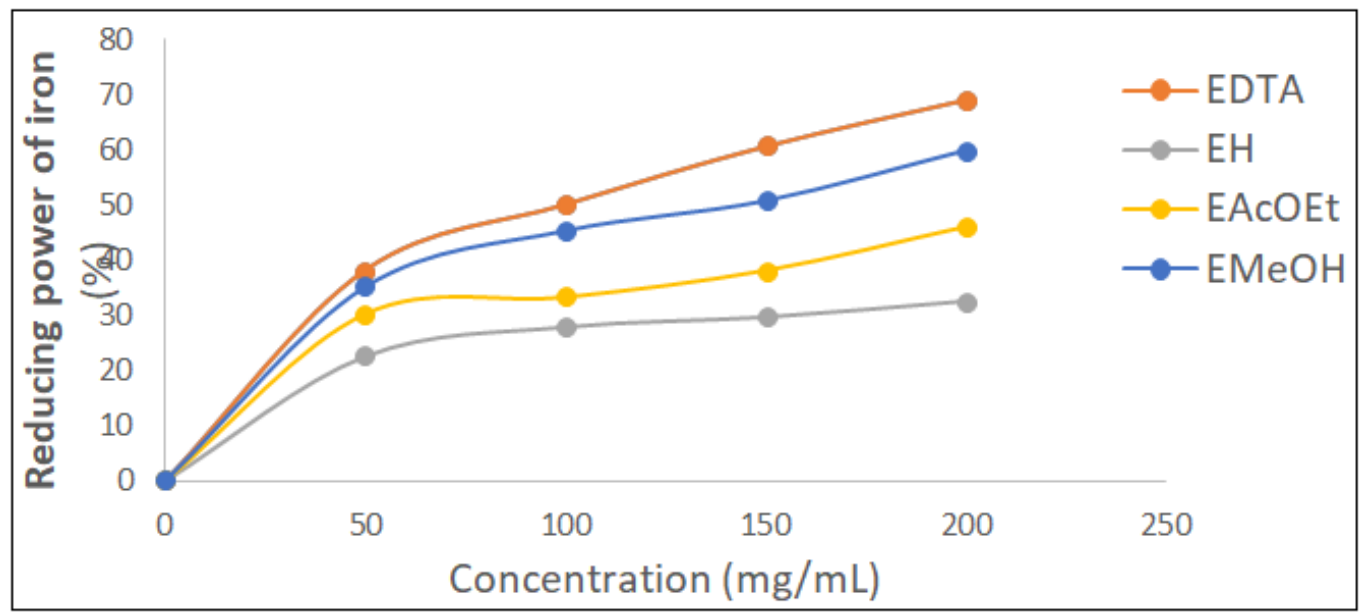

Fig-2: Variation of the chelating power according to the concentration of propolis

EDTA: Ethylene Diamine Tetraacetic Acid, EH: hexane extract; EAcOEt: ethyl acetate extract and EMeOH: methanol extract

\section{Anti-radical activity of propolis extracts with DPPH}

The antioxidant activity of the extracts is expressed in $\mathrm{IC}_{50}$, this parameter was used by several groups of researchers to present their results. It defines the effective concentration of the substrate which causes the loss of $50 \%$ of the DPPH radical activity (color). These $\mathrm{IC}_{50}$ are determined from the graphs (Figure-3) where the abscissa represents the concentration of the crude extract and the ordinate the antioxidant activity in percentage. It is $0.59 \mathrm{mg} / \mathrm{ml}$ for the hexane extract, $0.34 \mathrm{mg} / \mathrm{ml}$ for the ethyl acetate extract and $0.27 \mathrm{mg} / \mathrm{ml}$ for the methanol extract. The value $0.27 \mathrm{mg} / \mathrm{mL}$ is close to $\mathrm{IC}_{50}$ of BHT, the reference compound. The results are shown in Table-5. 
Table-5: Comparison of DPPH radical inhibition by propolis extracts and reference compounds

\begin{tabular}{|l|c|}
\hline Extracts & Inhibitory concentration $\mathbf{I C}_{\mathbf{5 0}}(\mathbf{m g} / \mathbf{m l})$ \\
\hline HE & 0.59 \\
\hline AcOEtE & 0.34 \\
\hline MeOHE & 0.27 \\
\hline BHT & 0.26 \\
\hline Vitamine C & 0.24 \\
\hline
\end{tabular}

HE: hexane extract, AcOEtE: ethyl acetate extract, MeOHE: methanol extract

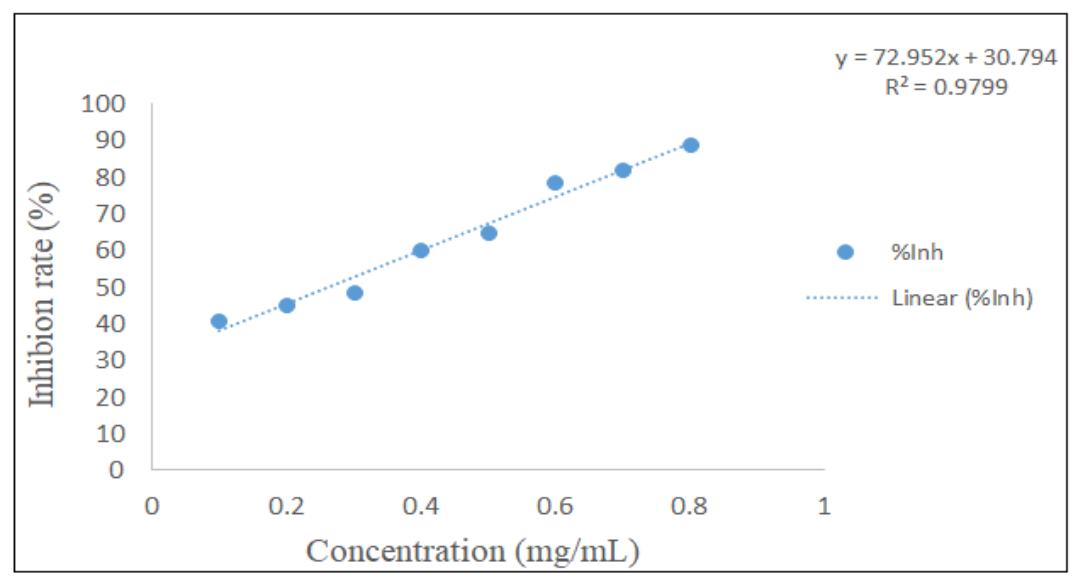

Fig-3: Calibration curve of BHT for the DPPH test

\section{DISCUSSION}

\section{Yield of Extraction}

Table-1 shows that the polarity of the solvent used and the yield obtained are inversely proportional. We can see here that hexane, an apolar solvent, presents an extraction yield of $52.08 \%$ whereas methanol, the most polar solvent, presents only a yield of $5.21 \%$. The yield of the hexane extract is higher than those obtained by Koundambaye [25] and Achi [26] from propolis from Meiganga (Adamaoua) which are respectively $44.80 \%$ and $47.55 \%$. This difference could be explained by the presence of terpenoids in our extracts, which is not reported in the work of Koundambaye [25] and Achi [26]. The work of Trusheva et al., [27] gave a yield of $13.87 \%$ using petroleum ether to extract propolis from Iran. This low yield would be due to the absence of apolar compounds in this propolis sample that petroleum ether could extract them unlike our studied sample. The yield of the ethyl acetate extract, $23.96 \%$ is comparable to that of Petrova et al., [28] who, extracting under the same conditions with ethyl acetate, obtained a yield of $20.03 \%$ on propolis from Mwingi in Kenya. Similarly the work of Koundambaye [25] also gave the yield which was $23.68 \%$. This result could be explained by the fact that these propolis samples could have identical source plants and consequently contain identical compounds or similar chemical properties. In general, our study sample is mostly composed of compounds of low polarities compared to those encountered in the literature due to the high extraction yield with hexane. Also, the extraction yields vary according to the propolis, the nature, the extraction method and the physicochemical characteristics of the solvents used, in particular their polarity. Indeed, the solubility of the substances contained in the vegetable matter in a given solvent depends on these properties. It follows that the extraction yields and the composition of the extracts vary from one solvent to another.

\section{Exploratory qualitative analysis of propolis extracts}

From the results obtained in Table-2 above, we note the presence of alkaloids in ethyl acetate and methanol extracts. This result is in agreement with the work of Preeti et al., [14] and Koundambaye [25] respectively on propolis from India and Meiganga (Adamaoua). We also note the presence of O-heterosides and C-heterosides in ethyl acetate and methanol extracts. Similarly, flavonoids are present in the methanol extract. These results also corroborate those of [29, 6, 30-33]. The presence of terpenes in all extracts confirms the work of Bankova et al., [31] that triterpenes are characteristic of propolis from tropical regions. Free anthracenes, sterols, saponins and coumarins were not detected in the different extracts. Finally, we can conclude that our study confirms the previous studies on propolis and also on its richness in polyphenols.

\section{Quantitative analysis of propolis extracts \\ Total Phenolic Content}

The total phenolic content of different propolis extracts show great variations, the variation goes from $0.68 \pm 0.09$ $\mathrm{g}$ EAG $/ 100 \mathrm{~g}$ to $12.64 \pm 0.23 \mathrm{gEAG} / 100 \mathrm{~g}$ of raw propolis. Considering the results obtained, we notice that the total 
polyphenol content is different from one sample to another. Similarly, these results are comparable to those of Bornes (329 mg EAG/g BM) and Fundặo (159 mg EAG/g BM) in Portugal [34] or Yeosu (212.7 mg EAG/g BM), Yangpyeong (160.6 mg EAG/g BM) and Boryung (172.3 mg EAG/g BM). On the other hand, the work done on Brazilian propolis by Alencar et al., [7] gave the polyphenol content which is about $232 \pm 22.3 \mathrm{mgEAG} / \mathrm{g}$. This result is far superior to those obtained in this study because Brazilian propolis is rich in flavonoids [35]. Similarly, the study carried out on propolis from Portugal shows total polyphenol contents higher than those of our extracts and which oscillate between $151.00 \pm$ 0.01 and $329.00 \pm 0.01 \mathrm{mg} \mathrm{EAG/g}$ of propolis, respectively for the Fundao and Bum regions [36]. These variations in phenolic compound content from one region to another or from one country to another confirm the influence of the origin of the plant material on the results.

\section{Total Flavonoid Content}

From Table-3, it can be seen that the total flavonoid content varies from $0.21 \pm 0.05 \mathrm{~g} \mathrm{EQ} / 100 \mathrm{~g}$ BM of hexane extract to $2.02 \pm 0.02 \mathrm{~g} \mathrm{EQ} / 100 \mathrm{~g} \mathrm{BM}$ of methanol extract. This content is different from that detected in Iranian propolis which is $77.9 \pm 0.39 ; 31.1 \pm 0.08$ and $12.2 \pm 0.33 \mathrm{mg}$ QE/mg propolis, respectively for Tehran, Isfahan and Khorsan samples [5]. This result shows that our studied sample consists of the low polarity compounds. Alencar et al [7] carried out a work on the sample from Brazil and they indicated a flavonoid content in the order of $43 \pm 0.1 \mathrm{mg}$ EQ / g raw propolis. Thus, we can conclude that the flavonoid content depends on the botanical region and therefore, the quantification of flavonoids can be very useful to establish a difference between propolis samples [37].

\section{Anti-oxidant activity of the propolis extracts Reducing power of iron}

Iron reducing power is often used as an indicator of a compound's ability to bind metal cations by forming a stable complex. Many authors consider the iron reducing power of a compound as a significant indicator of its antioxidant potential which is an important mechanism that examines the antioxidant action of phenolic compounds [38].

We find that the iron reducing power is proportional to the increase in the concentration of propolis extracts and EDTA, a synthetic antioxidant used as a reference. For a concentration of 0 to $50 \mathrm{mg} / \mathrm{ml}$, all the extracts present the same chelating power including also EDTA. But beyond this concentration, the ethyl acetate and methanol extracts show a very high reducing power compared to the hexane extract. This can be explained by the majority presence of phenolic compounds found in ethyl acetate and methanol extracts, because being good electron donors, phenolic compounds have this ability to fix metal cations by forming a stable complex and thus show a high chelating power. The analysis of the results reveals that the studied samples have a high chelating power and can totally transform $\mathrm{Fe}^{3+}$ into $\mathrm{Fe}^{2+}$, which means that these propolis extracts contain enough antioxidants to transform almost all ferricyanides.

\section{Anti-radical activity of propolis extracts with DPPH}

Considering Table-5, we notice that all the extracts have an antiradical power towards DPPH. The smaller the $\mathrm{IC}_{50}$ value, the more the extract is considered as a powerful antioxidant. These results corroborate well those of Ferhoum [39] who evaluated the anti-free radical activity of propolis from different regions of Algeria. On the other hand, the study carried out on ethanolic extracts of propolis from Portugal showed that the $\mathrm{IC}_{50}$ values obtained are of the order of $0.006 \mathrm{mg} / \mathrm{ml}$ and $0.025 \mathrm{mg} / \mathrm{ml}$ respectively for propolis from Bornes and Funddao [36]. These results, by far, lower than those found in our study, so the propolis from Portugal would have a greater antiradical power than our analyzed samples.

In conclusion, the antioxidant activities manifested by our extracts would be due to the presence of polyphenols, especially flavonoids. Therefore, propolis could be considered as a source of natural antioxidants.

\section{CONCLUSION}

Our work on phytochemical analysis of propolis extracts shows that propolis is rich in polyphenols and flavonoids. The quantification of phenolic compounds gave the content which varies from $0.68 \pm 0.09$ to $12.64 \pm 0.43 \mathrm{~g}$ EAG/100 MB for total polyphenols and a content of $0.21 \pm 0.05$ to $2.02 \pm 0.02 \mathrm{~g} \mathrm{EQ} / 100 \mathrm{MB}$ for total flavonoids respectively for the hexanolic and methanolic extracts The study of the free radical scavenging power of propolis extracts by DPPH test gave IC50s ranging from 0.59 to $0.27 \mathrm{mg} / \mathrm{mL}$ for hexanolic to methanolic extract respectively. The analysis of iron chelating activity also shows that these propolis extracts contain sufficient antioxidants to transform almost all ferricyanides.

\section{REFERENCES}

1. Hoyet, C. (2005). Le miel : De la source à la thérapeutique. Thèse de doctorat en pharmacie, Nancy, p106.

2. Blanc, M. (2010). Propriétés et usage médical des produits de la ruche. Thèse de Doctorat en Pharmacie, Limoges, $\mathrm{P} 144$. 
3. Kumazawa, S., Hamasaka, T., \& Nakayama, T. (2004). Antioxydant activity of propolis of various geographic origins. Food Chemistry, 84:329-373.

4. Uzel, A., \& Sorkun, K. (2005). Chemical Composition antimicrobial activities of four Anatolian propolis samples. Microbiological researh, 160:189-195.

5. Shiva, M., Mohammad, S., Manoochehr, H., Reza, A., Narsin, S., \& Seyed, N. O. (2006). Chemical Composition, oral toxicity and antimicrobial activity of Iranian propolis. Food Chemistry, 6:201-213.

6. Marcucci, M. (1995). Propolis Chemical Composition, biological properties and therapeutic activity.Apidologie, 26:83-89.

7. Alencar, S. M., Oldo, T. L. C., Castro, M. L., Cabral, I. S. R., Costa-Neto, C. M., Cury, J. A., Rosalen, P. L., \& Ikegaki, M. (2007). Chemical composition and biological activity of a new type Brazilian propolis: Red propolis. Journal of Ethnopharmacology, 113:278-283.

8. Mbawala, A., Ndi, A. C., Tchuenguem, F. F. N., Kamga, C., \& Etoa, F. X. (2003). Activité antibactérienne de quelques propolis originaires de l'adamaoua (Cameroun).Microb. Hyg. Alim, 15:33-38.

9. Mbawala, A., Tchuenguem, F. F. N., \& Milliere, J. B. (2009). Spectra of Antibacterial activity of propolis (PromaxC) Sample from locality of Adamaoua Province (Cameroun). Research journal of Microbiology, 4:150-157.

10. Mbawala, A., Roger, D., Tchuenguem, F. F. N., \& Milliere, J. B. (2010). In vitro susceptibility of same Bacteria Strains Collected from different Geographic origins in Cameroun. Journal of Food Technology, 8: 217-222.

11. Njintang, Y. N., Tatsadjieu, N. L., Ngakou, A., Danra, D., \& Tchuenguem, F. F. N. (2012). Antiradical activity and polyphenol content of ethanolic extracts of Propolis. International Journal of Biosciences , 4:56-63

12. Talla, E., Dabolé, B., Taiwe, G. S., Ngo Bum, E., Mbafor, J. T., Acthadé, A. D. T., Malik, R., Zulfiqar, A., Sidiki, N., Nguimbou, R. M., Coudhari, M. I. (2013). Antinoceptive Pentacyclic Triterpenoids from the Cameroonian Brown Propolis. Pharmacologia, 4:218-227.

13. Salomon, M. B., Talla, E., Ngassoum, M. B., Karole, T. T. R., Nyemb, J. N., \& Mahmout, Y. (2018). Optimization of microwave-assisted extraction of total phenol content and total flavonoids content from Anacardium occidental L.(Anacardeaceae) using response surface methodology. International Journal of Biochemistry and Biotechnology, International Scholars Journals (ISJ), 7(4), pp. 800-809.

14. Preeti, K., Neelima, R. K., \& Kusum, H. (2012). Phytochemical Screening and antibacterial activity of different extracts of propolis. International Journal of Pharmaceutical and Biological Research, 3:219-222.

15. Boizot, N., \& Charpentier, J. (2006). Méthode rapide d'évaluation du contenu en composés phénoliques des organes d'un arbre forestier dans Méthodes et Outils pour l'observation et l'évaluation des milieux forestiers, prairiaux et aquatiques. Le cahier des Techniques de l'Inra : numéro spécial: 7982.

16. Madjitoloum, B. S., Talla, E., Nyemb, J. N., Ngassoum, M. B., Tsatsop, T. R. K., \& Mahmout, Y. (2018). Comparative survey of three processes used for the extraction of total phenol content and total flavonoid content of Anacardium occidentale L. and the assessment of its antioxidant activity. African Journal of Biotechnology (AJB), Academic Journals (AJ). ISSN : 1684-5315 Vol. 17(40), pp. 1265-1273.

17. Hariri, E. B., Sallé, G., \& Andary, C. (1991). Involvement of flavonoids in the resistance of two poplar cultivars to mistletoe. Protoplasma, 162:20-26.

18. Laskar, R. A., Ismail, S., Roy N., \& Begum, N. A. (2010). Antioxydant activity of Indian propolis and its chemical constituents. Food Chemistry, 122: 233-237.

19. Rice-Evans, C. A., Miller, N. J., \& Paganga, G. (1996). Structure-antioxydant activity relatioships of flavonoids and phenolic acids. Free radical Biology \& Medecine, 20: 933-956.

20. Ricardo da Silva, J. M., Darmon, N., Fernandez, Y., \& Mitjavila, S. (1991). Oxygen free radical scavenger capacity in aqueous models of different procyanidins from grape seeds. Journal of Agricultural and Food Chemistry, 39:5491552

21. Benzie, I. F., \& Strain, J. (1996). The ferric reducing ability of plasma (FRAP) as a measure of antioxidant power: The FRAP assay. Analytical Biochemistry, 239:70-76.

22. Sharma Om, P., \& Bhat, T. K. (2009). DPPH antioxidant assay revisited. Food chemistry, 113:1202.

23. Tabart, J., Kevers, C., Pincemail, J., Defraigne, J., \& Dommes, J. (2009). Comparative antioxidant capacities of phenolic compounds meausured by various tests. Food Chemistry, 113:1226-1233.

24. Mohammdi, Z. (2004). Etude de pouvoir antimicrobien et antioxydant des huiles essentielles et flavonoïdes de quelques plantes de la région de Telmcen. Thèse de magistère, option : produit naturels, activités biologiques et synthèse, Alger, p147.

25. Koundambaye, M. (2011). Contribution à l'étude phytochimique et evaluation des proprieties antioxydantes d'un produit de la ruche: la Propolis (Meiganga, Adamaoua). Mémoire de Master en Chimie Organique, Université de Ngaoundéré, Cameroun. p71.

26. Achi, M. (2011). Etude phytochimique, evaluation des propriétés antioxydante et cytotoxique de la propolis de Meiganga (Adamaoua). Mémoire de Master en Chimie Organique, Université de Ngaoundéré, Cameroun. p67.

27. Trucheva, B., Todorov, I., Ninova, M., Najdenski, H., Daneshmand, A., \& Bankova, V. (2010). Antibacterial monoand sesquiterpene esters of benzoic acids from Iranian propolis. Chemistry Journal Central, 4:1-4. 
28. Petrova, A., Popova, M., Kuzmanova, C., Tsvetkova, I., Naydenski, H., Mulli, E., \& Bankova, V. (2010). New biologically active compounds from Kenyan propolis. Fitoterapia, 8:509-514.

29. Bankova, V., Dyulgerov, A., Popova, S., Evstativa, L., Kuleva, L., Pureb, O., \& Zamjansan, Z. (1992). Propolis produced in Bulgaria and Mongolia: phenolic compounds and plant origin. Apidologie, 23:79-85.

30. Hegazi, A. A. (1998). Propolis an overview. J. Bee Informed, 5:1-19.

31. Bankova, V. S., \& De Castro, M. L. (2000). Propolis: recent advances in Chemistry and plant origin .Apidologie, 31:3-5.

32. Bankova, V. (2005). Chemical diversity of propolis and the problem of standardization. Journal of Ethnopharmacology, 100: 114-117.

33. Bankova, V. (2005). Recent tends and important developments in propolis research. Evidence-based Complementary and Alternative Medecine, 2:29-32.

34. Monzote, F. L. (2011). Activity of Cuban propolis extracts on Leishmania amazonensis and Trichomonas vaginalis Nat Prod, 6:973-976.

35. Marcucci, M. C., Ferreres, F., Garcia-Viguera, C., Bankova, V. S., De Castro, S. L., Dantas, A. P., Valente, P. H. M., \& Paulino, N. (2001). Phenolic coumpounds from Brazilian propolis with pharmacological activities. Journal of Ethnopharmacology, 74: 105-112.

36. Leandro, M., Luis, G., Diase, J. A. P., \& Leticia, E. (2008). Antioxydant properties, total phenol and pollen analysis of propolis samples from Portugal. Food and Chemical toxicology, 46:3482-3485.

37. Shigeniro, K., Tomoka, H., \& Tsutomu, N. (2004). Antioxidant activity of propolis of various geographic origins. Food Chemistry, 84:329-339.

38. Wang, H., Zhao, M., Yang, B., Jiang, Y., \& Guohuo, R. (2008). Identification of polyphénols in tobacco leaf and their antioxydant and antimicrobial activities. Food Chemistry, 163:1399-1406.

39. Ferhoum, F. (2010). Analyses physico chimiques de la propolis locale selon les étages bioclimatiques et les deux races d'abeille locales. Magister en technologie alimentaire, Alger, p174.

CITATION: Madjitoloum Betoloum Salomon et al (2021). Determination of Total Phenolic and Total Flavonoid Contents and Assessment of Antioxidant Properties of Cameroon Propolis: Case of Boyo (North-West Cameroon). South Asian Res J Med Sci, 3(2): 16-24. 